\title{
16. CENOZOIC OSTRACODA FROM DEEP SEA DRILLING PROJECT LEG 95 OFF NEW JERSEY (SITES 612 AND 613) ${ }^{1}$
}

\author{
Thomas M. Cronin and Ellen E. Compton-Gooding, U.S. Geological Survey, Reston ${ }^{2}$
}

\begin{abstract}
Ninety-three samples from DSDP Leg 95, Sites 612 and 613, were examined for ostracodes to aid in the study of paleoceanography and paleodepth. In total, more than 25 genera were recovered. The most abundant and diverse ostracode assemblages were from the middle Eocene at both sites; lower and upper Eocene and Pliocene-Pleistocene assemblages were less abundant and were dominated by only three or four species.

The middle Eocene assemblages were the most diagnostic of paleoenvironment and suggest water depths of 1000 to $2000 \mathrm{~m}$. These assemblages are similar to other middle Eocene assemblages known from the Caribbean and North Atlantic, and signify a relatively cosmopolitan fauna that inhabited moderately deep but relatively warm bottom waters.
\end{abstract}

\section{INTRODUCTION}

The principal scientific objectives of drilling at Sites 612 and 613 (DSDP Leg 95) were to determine Cenozoic depositional environments, to date biostratigraphic gaps, and to evaluate these data in the light of sea-level changes and paleoceanography for the middle continental slope and upper rise. Ostracodes from ninety-three $20-\mathrm{cm}^{3} \mathrm{sam}$ ples were studied to aid in achieving these objectives. In addition to yielding regional paleodepths, the Eocene faunas discovered at Sites 612 and 613 also fill a geographic gap in our data on Eocene bathyal faunas and thus contribute to our understanding of deep-water ostracode biogeography.

Cenozoic ostracodes from several DSDP sites in the North Atlantic have been studied previously. The following papers were used in determining paleonvironments and in taxonomic identifications discussed later: Benson (1972a, 1972b, 1974, 1975, 1977), Benson and SylvesterBradley (1971), Bold (1969), Brady (1880), Ducasse and Peypouquet (1979), Guernet (1982), Le Roy and Levinson (1974), Peypouquet (1975), Puri and Hulings (1976), Steineck (1981), Steineck et al. (1984), and Tressler (1941). Our report must be considered preliminary until other deep-sea material can be compared directly with the material from Leg 95.

\section{SUMMARY OF OSTRACODE FAUNAS}

\section{Site 612 (Table 1)}

Ostracodes are relatively common in the middle and upper Eocene sediments at this site, but are rare in the lower Eocene and Pliocene-Pleistocene sediments. Juvenile specimens usually constitute more than fifty percent of each sample. A low-diversity assemblage, including Krithe, Cytherella, Argilloecia, and Paranesidea, characterizes the lower Eocene section at Site 612. There is a distinct faunal change near the lower Eocene-middle Eo-

\footnotetext{
${ }^{1}$ Poag, C. W., Watts, A. B., et al., Init. Repts. DSDP, 95: Washington (U.S. Govt. Printing Office).

2 Address: U.S. Geological Survey, Mail Stop 970, Reston, VA 22092.
}

cene transition that corresponds approximately to the boundary between lithostratigraphic Units III and II. This change is characterized by an increase in diversity and the appearance of the following taxa: Abyssocythere, Agrenocythere, Bythocypris Cytheropteron, Eucythere, Henryhowella, "Loxoconcha," Macrocypris, Phacorhabdotus, "Hazelina," Trachyleberidea, and Xestoleberis. These taxa, plus abundant Krithe, Cytherella, and Paranesidea, occur in most middle Eocene samples.

Another distinct faunal change occurs at the transition from middle Eocene to upper Eocene-Oligocene sediments (Cores 22 and 21), where Argilloecia, Bairdoppilata, Bythocypris, Cytheropteron, Eucythere, "Hazelina," Phacorhabdotus, and "Thalassocythere" have their uppermost occurrences. The upper Eocene is characterized by the occurrence of the Messinella, a genus that is restricted to this age at this site, although it occurs in the middle Eocene of Site 613. Henryhowella constitutes a greater proportion of the upper Eocene assemblage than it does in older sediments.

Pliocene and Miocene sediments from Cores 8 to 13 were barren of ostracodes. A sparse assemblage that includes Henryhowella, Krithe, Cytheropteron, Heterocyprideis, Finmarchinella, and Muellerina occurs in Cores 1 to 7 .

\section{Site 613 (Table 2)}

Site 613 yielded ostracode assemblages similar to those at Site 612 in the abundance of Krithe, Cytherella, and Paranesidea in middle Eocene and the relative sparseness of the lower Eocene and Pliocene-Pleistocene assemblages. The following important differences should be noted, however, for the middle Eocene at the two sites:

\begin{tabular}{|c|c|c|}
\hline & Site 612 & Site 613 \\
\hline Messinella & Absent & Common \\
\hline Trachyleberidea & Few & Abundant \\
\hline "Hazelina" & Absent & Few \\
\hline "Loxoconcha" & Common & Few \\
\hline Aratrocypris sp. & Few & Absent \\
\hline Abyssocythere & Common & Absent \\
\hline "Bairdia" sp. & Few & Absent \\
\hline
\end{tabular}


Table 1. Ostracoda from Hole 612 (water depth $1404 \mathrm{~m}$ ).

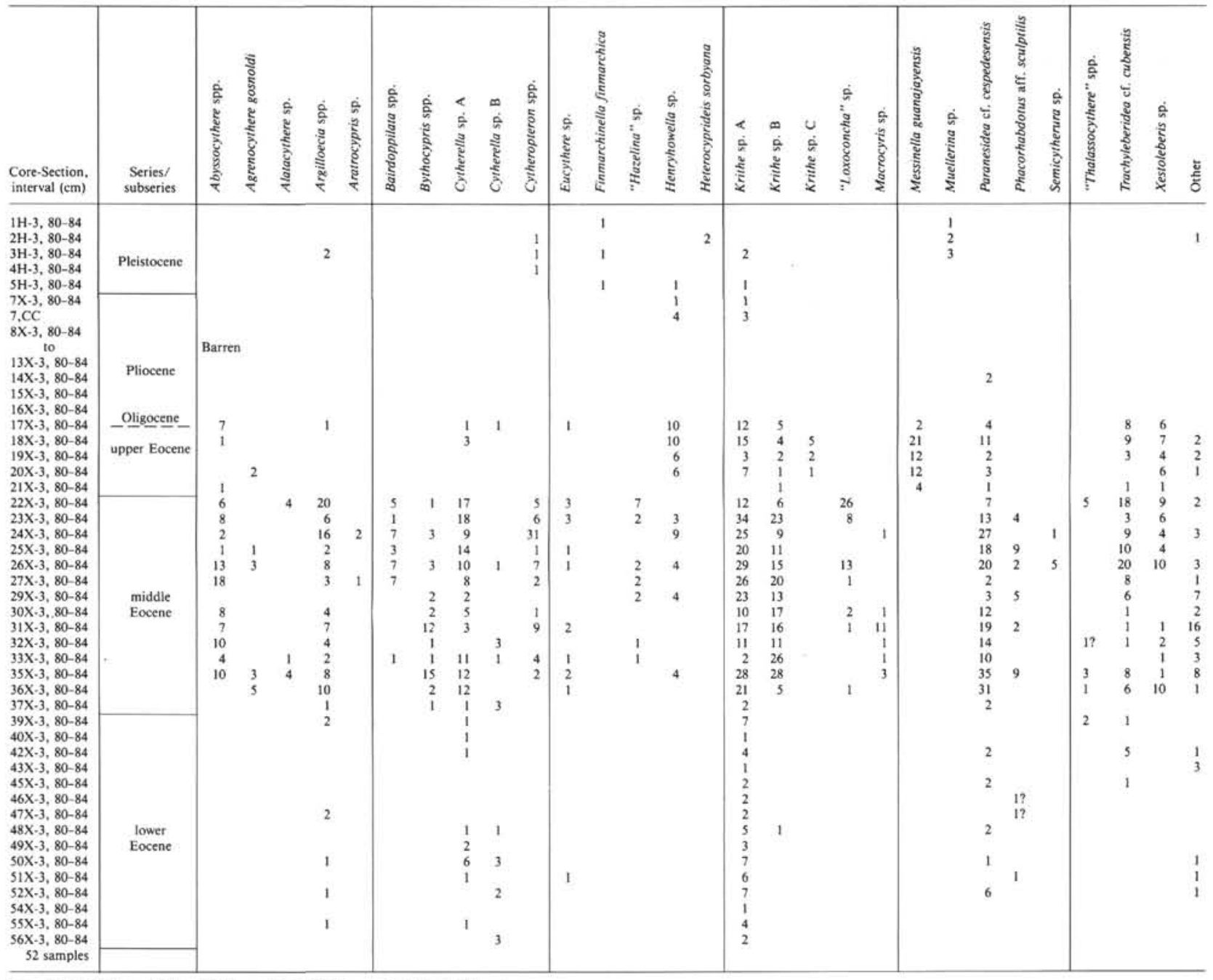

Note: $15 \mathrm{X}-3,80-84 \mathrm{~cm}, 16 \mathrm{X}-3,80-84 \mathrm{~cm}, 41 \mathrm{X}-3,80-84 \mathrm{~cm}$ and $44 \mathrm{X}-3,80-84 \mathrm{~cm}$ barren

These differences probably signify differences in paleodepth and/or oceanographic conditions, which are discussed in the section following.

\section{EOCENE ENVIRONMENTS}

Several characteristics of deep-water ostracodes and their populations have been used to reconstruct paleoenvironments and to estimate paleodepth. The most commonly used of these characteristics are (1) environmental evidence (using modern distribution data on a genus or species to infer past conditions), (2) morphologic evidence (such as the presence or absence of eyes, carapace size and ornament, vestibule size), and (3) species diversity and abundance (Benson, 1984). Ostracodes have proved particularly useful in determining conditions during the Eocene-Oligocene, when major oceanographic changes occurred (Benson, 1975).

The location of Sites 612 and 613 on a continental margin offers an opportunity to compare local changes in ostracode assemblages with contemporaneous sequences from other DSDP cores and outcrop sections, and with global paleoceanographic events. Benson (1975) in- ferred, from the changes in deep-sea ostracode faunas, a period of transition in the world ocean from a thermospheric state to a two-layer psychrospheric ocean about 40 m.y. ago. More recently, Benson et al. (1984), drawing on data from 1044 ostracode samples from 156 deep-sea sites, have characterized the change in ostracodes between 40 and $36 \mathrm{~m}$.y. ago as a gradual turnover, characterized by an increase in origination of new taxa related to the origin of the psychrosphere.

Ducasse and Peypouquet (1979) described a sequence of ostracodes from the Rockall Banks area in which lower Eocene assemblages of Cytherella and Krithe were replaced in the middle and upper Eocene by more diverse assemblages including Atlanticythere, Trachyleberidea, Bythocypris, and Bairdia. At DSDP Site 401, lower to middle Eocene to Oligocene ostracode faunas were abundant and moderately diverse. The trend toward increasing diversity is also present at Sites 612 and 613, where the lower Eocene faunas are sparse and of low diversity (primarily krithids, Cytherella, and Paranesidea) compared with the middle Eocene faunas. Although this trend might be related to local events such as subsidence (Du- 
Table 2. Ostracoda from Hole 613 (water depth $2323 \mathrm{~m}$ ).

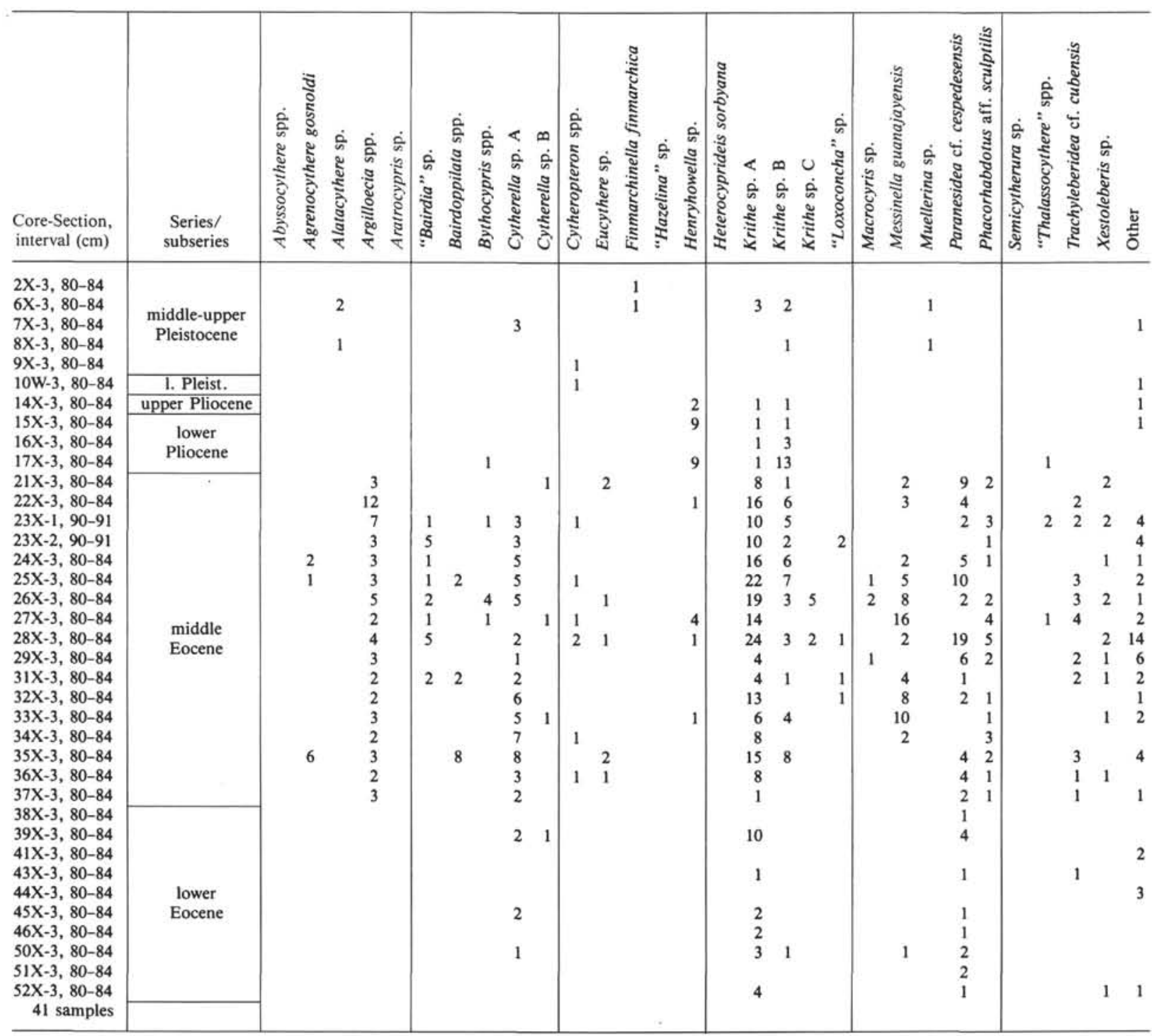

Note: The following samples were barren: $12 X-3,80-84 \mathrm{~cm} ; 13 \mathrm{X}-3,80-84 \mathrm{~cm} ; 18 \mathrm{X}-3,80-84 \mathrm{~cm} ; 19 \mathrm{X}-3,80-84 \mathrm{~cm}$.

casse and Peypouquet [1979] inferred subsidence for the Rockall area), increased diversity in the middle Eocene may also be a more widespread, possibly global, trend. The same trend occurs at both Site 612 (1386 m water depth) and the downdip Site 613 (2309 $\mathrm{m}$ water depth). Further, Benson et al. (1984, fig. 3) show a rise in the Shannon-Wiener diversity index for their ostracode data from this same time interval, although Sites 612 and 613 do not necessarily have as complete a stratigraphic record as was available to Benson.

Steineck et al. (1984) described Eocene and Oligocene ostracodes from the Oceanic Formation of Barbados and provided a useful comparison of these faunas with other Eocene and Oligocene ostracodes from the North and South Atlantic and the Caribbean. They concluded that a major, circumequatorial cosmopolitan deepwater ostracode fauna was characterized by smoothshelled krithids, Cytherella, Paranesidea cespedesensis, and, in lesser numbers, Henryhowella, Agrenocythere, and Phacorhabdotus. Ostracodes in this fauna were blind, a trait that signifies paleodepths below the photic zone (below 600-900 m). Similarly, species lacking eye tubercles dominate the ostracodes from Sites 612 and 613 (see Plates 1-8). Steineck et al. (1984) interpreted the Eocene faunas as signifying paleodepths of about 2000 to 2500 $\mathrm{m}$. The middle Eocene ostracode assemblages at Sites 612 and 613 are dominated by the same taxa as those from the Eocene of Barbados, and it is interesting to note the additional similarity in the relatively low proportions of Agrenocythere and the more moderate numbers of Phacorhabdotus.

The most important differences between the two faunas are (1) the greater abundance of Abyssocythere at Site 612 , (2) the abundance of Trachyleberidea at Sites 612 and 613, and (3) the occurrence of "Hazelina" and "Thalassocythere" at Site 612. If the two faunas are assumed to be generally contemporaneous, these differences might be due to minor biogeographic differences or, more likely, differences in paleodepth. The abundance of Trachyleberidea suggests slightly shallower depths than 
the 2000 to $2500 \mathrm{~m}$ for the Oceanic Formation. Ducasse and Peypouquet (1979) suggest that this genus occurs below $1000 \mathrm{~m}$. Cronin (1983) found it most common in the slope off the southeastern U.S. between 400 and $900 \mathrm{~m}$, but this study did not examine samples deeper than $1100 \mathrm{~m}$. Further, modern species of Trachyleberidea may have depth ranges quite different from their Tertiary congeners, and the significance of this genus with regard to paleodepth requires additional study. The significance of the abundant undescribed species of Abyssocythere is not understood, but its absence at Site 613 suggests that it preferred the shallower depths of Site 612 in this region during the middle Eocene.

Species diversity should be used as an indicator of paleodepth with the knowledge that there are conflicting opinions about diversity patterns in the deep sea (Benson, 1972a, 1984; Whatley, 1983). Data are especially sparse for the bathyal zone (Cronin, 1983), although Peypouquet (1980) indicates a moderate diversity in the epibathyal zone (400-1500 m) and Cronin (1983) found surprisingly high species diversity in epibathyal sediments of the Florida-Hatteras Slope and the Blake Plateau.

In summary, the Eocene ostracode faunas of Sites 612 and 613 fit into the general pattern of a cosmopolitan fauna inhabiting a circumglobal belt, although minor differences with respect to faunas from more equatorial regions may signify minor biogeographic differences at the margins of this ocean. Middle Eocene faunas probably represent paleodepths between 1000 and $2000 \mathrm{~m}$. A significant change in ostracode faunas occurs at the Eocene-Oligocene transition, but the Oligocene faunas are not abundant enough for comparison with contemporaneous faunas elsewhere.

\section{TAXOMOMIC NOTES}

The following comments discuss possible taxonomic affinities of Leg 95 species with those described or illustrated from other regions. Because bathyal and abyssal ostracodes have only recently attracted attention, there remains a high degree of uncertainty in species-level taxonomy. This problem is complicated by our poor understanding of bathyal and abyssal biogeography, intraspecific variability in carapace morphology, and the seemingly cosmopolitan distribution of some species. Nevertheless, the situation is improving; additional studies that include high-quality scanning electron photographs are appearing, and specialists are beginning to link ostracodes from exposed onshore sections with those in deep-sea drilling material (Steineck et al., 1984). Illustrated specimens are deposited in the U.S. Museum of Natural History (USNM numbers 401504-401553).

Abyssocythere spp. Three morphotypes are present. The type illustrated in Plate 3, Figure 5 has an ornament pattern slightly different from the type in Plate 3, Figures 2 and 4 . No previous illustrations of these species are known to the authors.

Agrenocythere gosnoldi Benson, 1972 (Plate 4, Figs. 2, 4). Benson (1972b) described this species from outcrops of middle Eocene sediments in submarine canyons along the east coast of the United States.

Alatacythere sp. (Plate 1, Fig. 2). This species resembles A. ivani Howe, 1951, which occurs in the Tertiary of the Atlantic and Gulf Coastal Plains.

Aratrocypris sp. (Plate 8, Fig. 4). Whatley et al. (1985) described this genus from Tertiary DSDP sites in the southwestern Pacific. Cronin (1983) also found a related species in modern sediments of the Blake Plateau off the Florida coast.

"Bairdia" sp. (Plate 8, Fig. 2). This species is referred to as Gen. $3 \mathrm{sp.}$ by Guernet (1982), Bairdia sp. 6 by Ducasse and Peypouquet (1979), and "Bairdia" sp. 3 by Steineck et al. (1984).
Bairdoppilata spp. (Plate 8, Fig. 1). Most forms grouped in this category resemble the Eocene species Bairdoppilata cassida (van den Bold, 1946) illustrated by Steineck et al. (1984).

"Costa" aff. "C." barri van den Bold, 1960. (Plate 4, Fig. 1). A few specimens of this species were found in Hole 613, Core 29 (listed in "other" category in Table 2). This species appears to be related to several other species frequently found in bathyal deposits in the Caribbean and Gulf of Mexico region. Guernet (1982) illustrated a similar form (Gen. 1 sp., pl. 5, figs. 2-5) from the middle Eocene of the Bahaman Basin. Costa bellipulex Le Roy 1974 may be related to this species. The resemblance of these forms to Agrenocythere should be noted, and until confirmed or denied by further study, the generic assignment remains uncertain.

"Hazelina" sp. (Plate 1, Fig. 4). In overall shape and the presence of three prominent longitudinal ridges, the species resembles Hazelina sp. 2 illustrated by Ducasse and Peypouquet (1979) from the Rockall Plateau (DSDP Leg 48)

Henryhowella sp. Two morphotypes were found at Sites 612 and 613. Plate 1, Figure 6 illustrates a reticulate form having subdued longitudinal ridges; Plate 1, Figure 5 and Plate 2, Figure 1 show a form lacking ridges but characterized by pustules and spines formed at the intersections of the reticulation.

Krithe spp. This genus is represented by several morphotypes, but it is not clear how many of these are distinct species and how many are ecophenotypic variants within single species. Dr. W. A. van den Bold (Louisiana State University) has kindly pointed out that the specimen illustrated in Plate 6, Figure 4 strongly resembles $K$. crassicaudata van den Bold, 1960.

"Loxoconcha" sp. (Plate 5, Fig. 3). This form is tentatively placed in the typically shallow-water genus Loxoconcha. Deeper-water species having a compressed periphery might belong in a separate genus.

Messinella guanajayensis (van den Bold, 1946) (Plate 7, Figs. 1, 2). This is probably the same species that Steineck et al. (1984) found in several locations in the Cenozoic of the Caribbean.

Paranesidea cf. cespedecensis (van den Bold, 1946) (Plate 8, Fig. 3). Some of these forms might belong to the morphologically similar species Bairdia oarion van den Bold, 1972 (see Steineck, 1981).

Phacorhabdotus aff. P. sculptilis (Alexander, 1934) (Plate 1, Fig. 3). Phacorhabdotus is common in Upper Cretaceous and Cenozoic bathyal sediments in the Gulf of Mexico and western Atlantic Ocean, and has potential for biostratigraphic correlation. The species found in the middle Eocene at Sites 612 and 613 differs from $P$. sculptilis in having much shorter and thinner dorsal, medial, and ventral longitudinal ridges.

"Thalassocythere" spp. The lower Pliocene specimen illustrated in Plate 2, Figure 3 is probably " $T$." acanthoderma (Brady, 1880); specimens from the Eocene represent a different species.

Trachyleberidea cf. cubensis (van den Bold, 1946) (Plate 4, Figs. 5, 6). This species assignment is tentative pending detailed study of this genus.

Xestoleberis sp. Some of the specimens from Sites 612 and 613 can be assigned to $X$. chamela van den Bold, 1960.

\section{ACKNOWLEDGMENTS}

Thanks go to C. Wylie Poag for offering the Leg 95 material for study and for reviewing the manuscript, to Page C. Valentine and A. Palmer for obtaining samples on the ship, and to R. Margerum and W. A. van den Bold for helpful reviews.

\section{REFERENCES}

Alexander, C. I., 1934. Ostracoda of the Midway (Eocene) of Texas. $J$. Paleontol., 8:206-237.

Benson, R. H., 1972a. Preliminary report on the ostracods of Holes 117 and 117 A. In Laughton, A. S., Berggren, W. A., et al., Init. Repts. DSDP, 12: Washington (U.S. Govt. Printing Office), 427432.

1972b. The Bradleya problem, with descriptions of two new psychrospheric ostracode genera, Agrenocythere and Poseidonamicus (Ostracoda: Crustacea). Smithson. Contrib. Paleobiol., 12:1138.

1974. Preliminary report on the ostracodes of Leg 24. In Fisher, R. L., Burce, E. T., et al., Init. Repts. DSDP, 24: Washington (U.S. Govt. Printing Office), 1037-1043. 
1975. The origin of the psychrosphere as recorded in changes of deep-sea ostracode assemblages. Lethaia, 8:69-83.

1977. The Cenozoic ostracode faunas of the São Paulo Plateau and the Rio Grande Rise (DSDP Leg 39, Sites 356 and 357). In Supko. P. R., and Perch-Nielsen, K., et al., Init. Repts. DSDP, 39: Washington (U.S. Govt. Printing Office), 869-883.

1984. Estimating greater paleodepths with ostracodes, especially in past thermospheric oceans. Palaeogeogr., Palaeoclimatol., Palaeoecol., 48:107-141.

Benson, R. H., Chapman, R. E., and Deck, L. T., 1984. Paleoceanographic events and deep-sea ostracodes. Science, 224:1334-1336.

Benson, R. H., and Sylvester-Bradley, P. C., 1971. Deep-sea ostracodes and the transformation of ocean to sea in the Tethys. In Oertli, H. J., (Ed.), Paléoécologie des Ostracodes (Pau, 1970). Bull. Cent. Rech. Pau- SNPA, 5(Suppl.):63-91.

Bold, W. A. van den, 1946. Contribution to the study of Ostracoda with special reference to the Tertiary and Cretaceous microfauna of the Caribbean region [dissertation]. Utrecht Univ. (Publ. Amsterdam [J. H. DeBussy]), pp. 1-167.

1960. Eocene and Oligocene Ostracoda of Trinidad. Micropaleontology, 6:145-196.

1969. Messinella, a new genus of Ostracoda in the Caribbean Cenozoic. Micropaleontology, 15:397-400.

Brady, G. S., 1880. Report on the Ostracoda dredge by H.M.S. Challenger during the years 1873-1876. Report of Scientific Results of Voyage H.M.S. Challenger, Vol. 1, Part III. Zoology, pp. 1-184, pl. 1-44.

Cronin, T. M., 1983. Bathyal ostracodes from the Florida-Hatteras Slope, the Straits of Florida, and the Blake Plateau. Mar. Micropaleontol., 8:89-119.

Ducasse, O., and Peypouquet, J. P., 1979. Cenozoic ostracodes; their importance for bathymetry, hydrology, and biogeography. In Montadert, L., Roberts, D. G., et al., Init. Repts. DSDP, 48: Washington (U.S. Govt. Printing Office), 343-363.

Guernet, C., 1982. Contribution à l'étude des faunes abyssales: Les ostracodes Paléogènes du Bassin des Bahamas, Atlantique Nord (DSDP Leg 44). Rev. Micropaleontol., 25:40-56.
Le Roy, D. O., and Levinson, S. A., 1974. A deep-water Pleistocene microfossil assemblage from a well in the northern Gulf of Mexico. Micropaleontology, 20:1-37.

Peypouquet, J. P., 1975. Le renouvellement de la faune d'ostracodes du Bassin de Rockall entre le Miocène et le Pléistocène supérieur, intérêt paléohydrologique. Bull. Soc. Geol. France, (7)XVII:886896.

1980. Les relations ostracodes-profondeur. Principes applicables pendant le Cénozoique. Bull. Inst. Geol. Bassin d'Aquit., 28:13-28.

Puri, H. S., and Hulings, N. C., 1976. Designation of lectotypes of some ostracods from the Challenger Expedition. Bull. Brit. Mus. (Nat. Hist.) Zool., 29:254-315.

Steineck, P. L., 1981. Upper Eocene to middle Miocene ostracode faunas and paleoceanography of the North Coastal Belt, Jamaica, West Indies. Mar. Micropaleontol., 6:339-366.

Steineck, P. L., Breen, M., Nevins, N., and O'Hara, P., 1984. Middle Eocene and Oligocene deep-sea Ostracoda from the Oceanic Formation, Barbados. J. Paleontol., 58:1463-1496.

Tressler, W. L., 1941. Geology and biology of North Atlantic deep-sea cores between Newfoundland and Ireland, Part 4. Ostracoda. U.S. Geol. Surv. Prof. Pap., 196-C:95-106.

Whatley, R. C., 1983. Some aspects of the palaeobiology of Tertiary deep-sea Ostracoda from the S. W. Pacific. J. Micropalaeontol., 2: 83-104.

Whatley, R. C., Ayress, M., Downing, S., Harlow, C., and Kesler, K., 1985. Aratrocypris, an enigmatic new cyprid ostracod from the Tertiary of DSDP sites in the S. W. Pacific. J. Micropaleontol., 4: 69-79.

Date of Initial Receipt: 6 May 1985

Date of Acceptance: 18 October 1985 


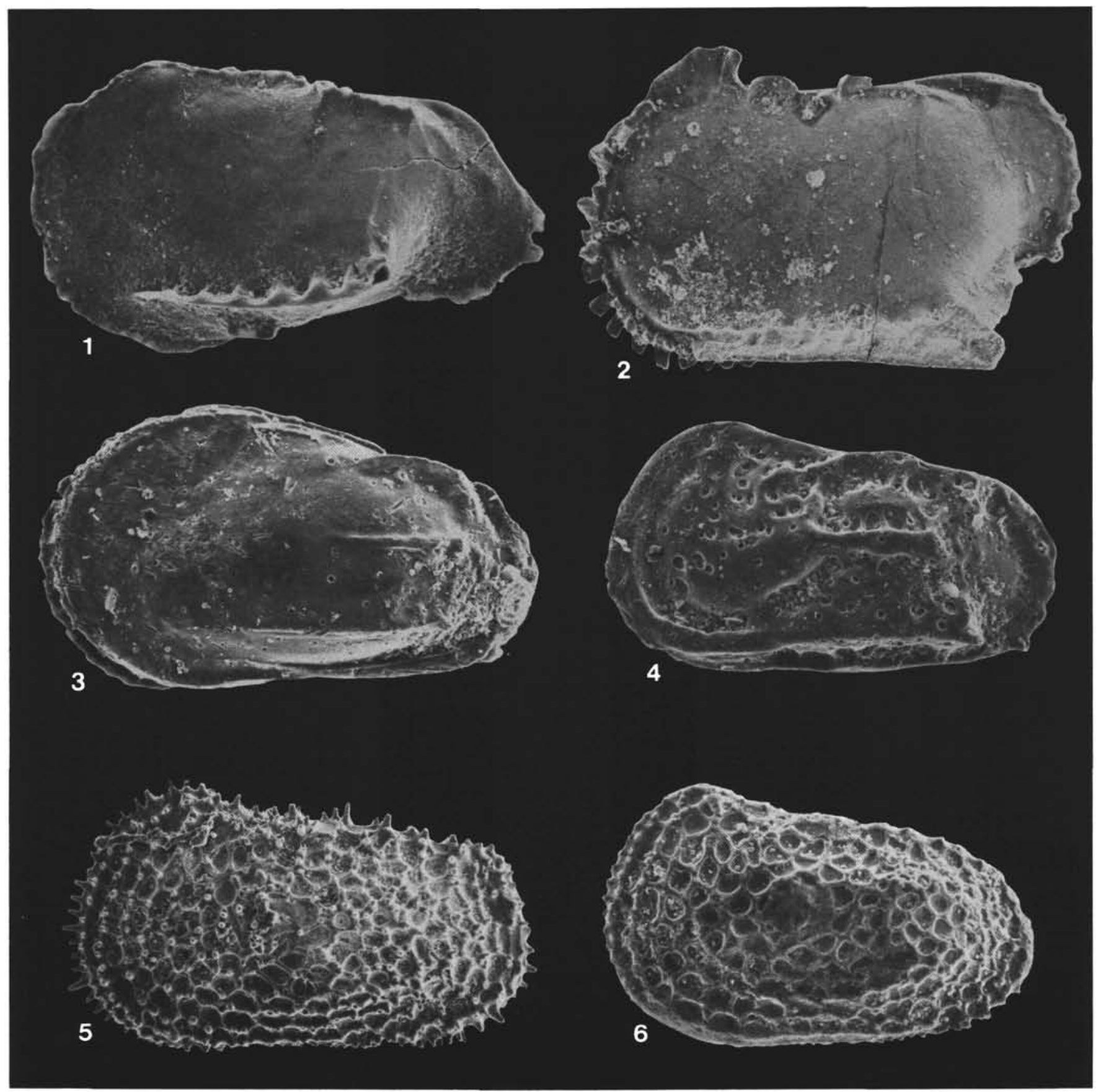

Plate 1. (Three-part designations beginning with 612 or 613 are DSDP section numbers.) 1. Pterygocythereis inexpectata Blake, $1929, \times 120$, exterior left valve, juvenile, Pleistocene, 613-6X-3, USNM 401504 (specimen broken after photography). 2. Alatacythere sp., $\times 72$, exterior left valve, adult female, middle Eocene, 612-24X-3, USNM 401505. 3. Phacorhabdotus aff. P. sculptilis (Alexander, 1934), $\times 110$, exterior left valve, adult female, middle Eocene, 612-25X-3, USNM 401506. 4. "Hazelina" sp., $\times 120$, exterior left valve, adult female, middle Eocene, 612-26X-3, USNM 401507. 5, 6. Henryhowella sp., exterior left valve, adult male, (5) $\times 100$, upper Eocene, 612-19X-3, USNM 401510, (6) $\times 120$, middle Eocene, 613-33X-3, USNM 401509. 


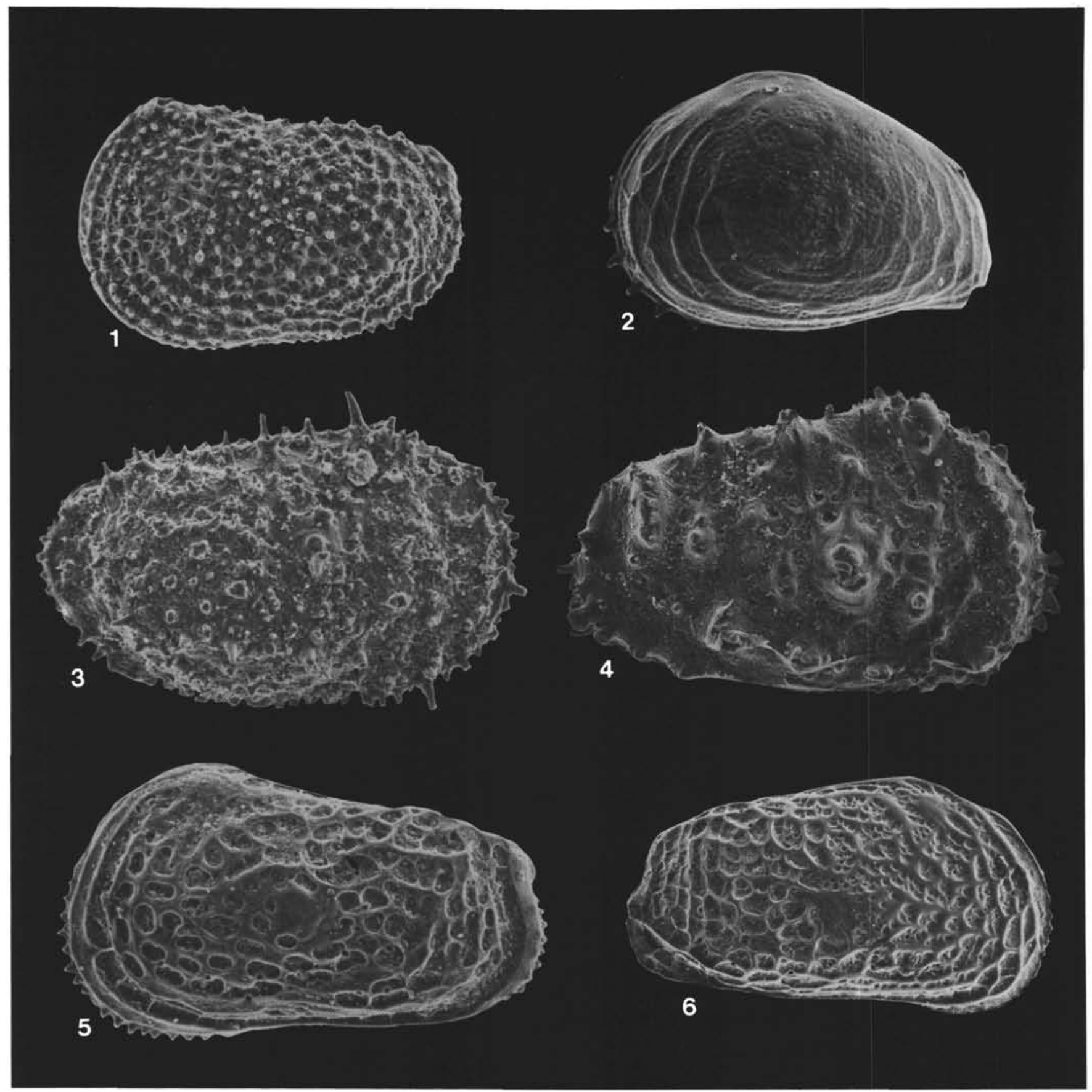

Plate 2. (Three-part designations beginning with 612 or 613 are DSDP section numbers.) 1. Henryhowella sp., $\times 110$, exterior left valve, juvenile female, upper Pliocene, 613-14X-3, USNM 401508. 2. Heterocyprideis sorbyana (Jones, 1857), $\times 180$, exterior left valve, juvenile female, Pleistocene, 612-2H-3, USNM 401518 (specimen broken after photography). 3. "Thalassocythere" sp., $\times 94$, exterior right valve, juvenile female, lower Pliocene, 613-17X-3, USNM 401511. 4. "Acanthocythereis" dunelmensis (Norman, 1865), $\times 72$, exterior right valve, adult female, Pleistocene, 613-7X-3, USNM 401519. 5. Muellerina sp., $\times 150$, exterior left valve, juvenile female, Pleistocene, 613-6X-3, USNM 401526. 6. Finmarchinella finmarchica (Sars, 1865), $\times 130$, exterior right valve, juvenile female, Pleistocene, 612-1H-3, USNM 401527. 


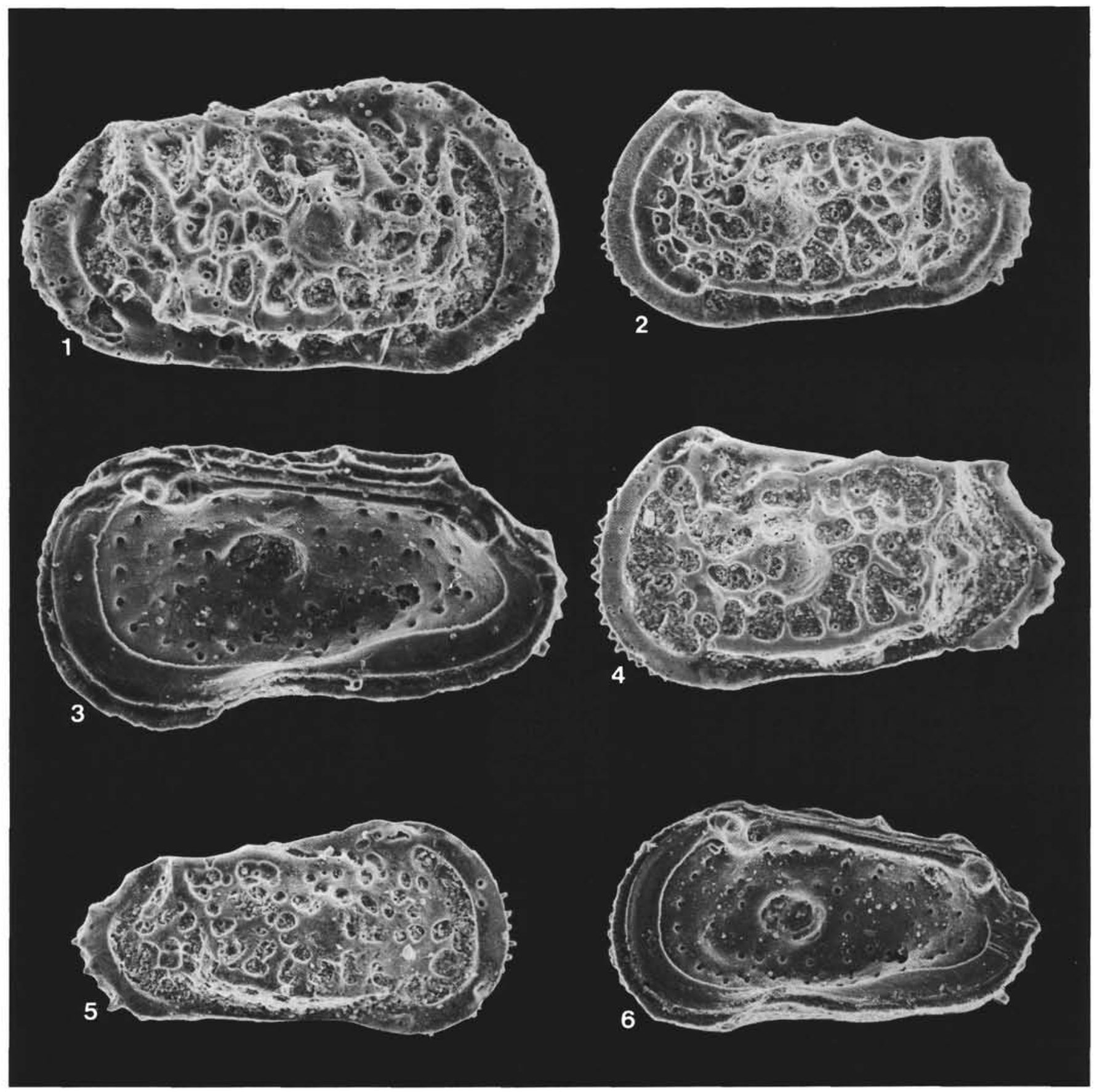

Plate 3. Abyssocythere spp. (All specimens magnified $\times 120$ unless otherwise indicated. Three-part designations beginning with 612 and 613 are DSDP section numbers.) 1, 3. $\times 150$, adult female, middle Eocene, 612-23X-3, (1) exterior right valve, USNM 401516, (3) interior right valve, USNM 401517. 2. exterior left valve, adult male, upper Eocene, 612-21X-3, USNM 401513. 4. exterior left valve, adult female, upper Eocene, 612-17X-3, USNM 401512. 5, 6. Middle Eocene, 612-27X-3, (5) exterior right valve, adult male, USNM 401514, (6) interior right valve, adult female, USNM 401515. 

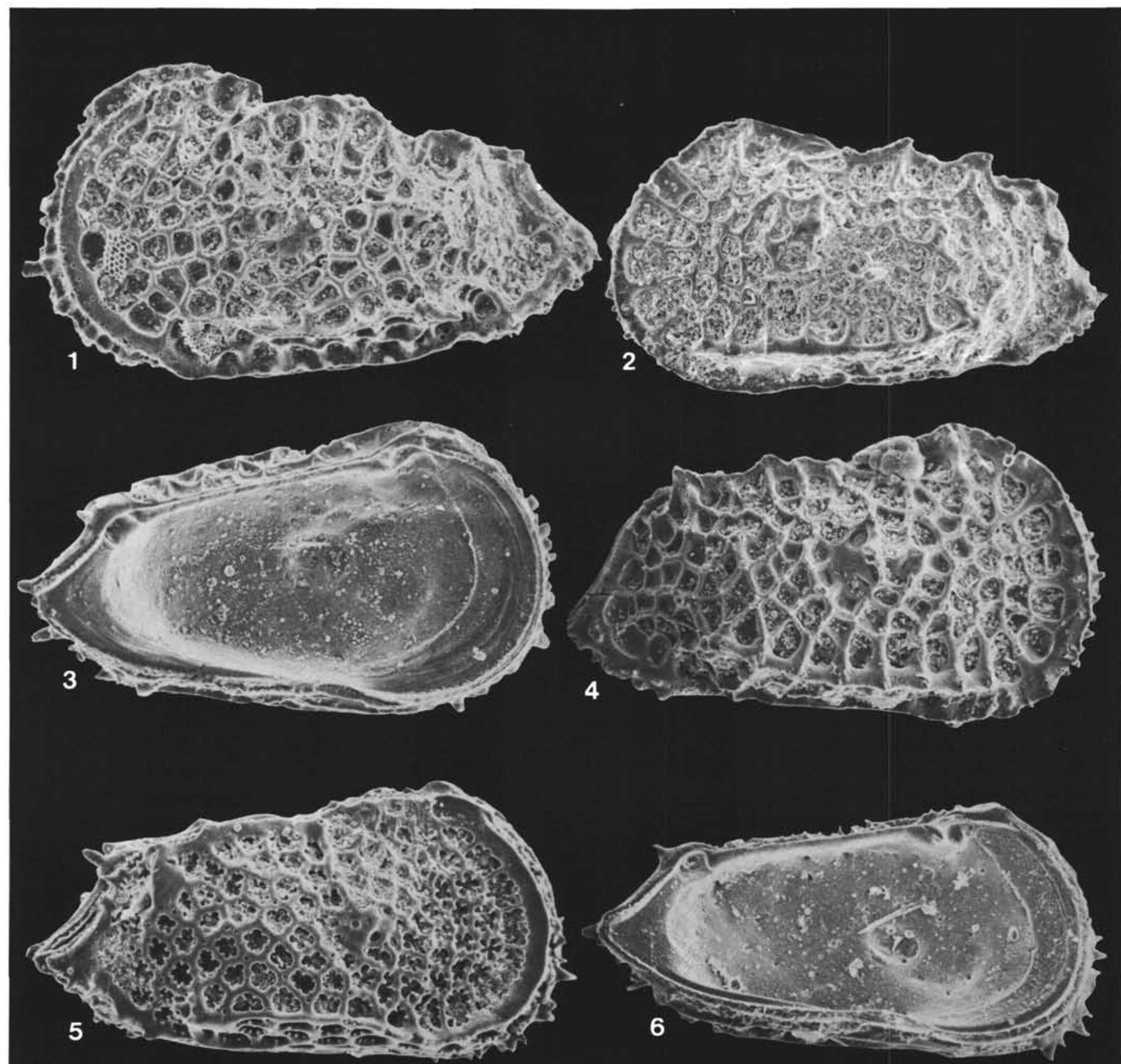

Plate 4. (All specimens magnified $\times 100$. Three-part designations beginning with 612 or 613 are DSDP section numbers.) 1. "Costa" aff. "C." barri van den Bold, 1960, exterior left valve, adult female, middle Eocene, 612-29X-3, USNM 401520. 2, 4. Agrenocythere gosnoldi Benson, 1972, juvenile female, middle Eocene, (2) exterior left valve, 613-35X-3, USNM 401521, (4) exterior right valve, 612-26X-3, USNM 401523. 3. "Costa" cf. "C." barri van den Bold, 1960, interior left valve, adult female, middle Eocene, 612-26X-3, USNM 401522. 5, 6. Trachyleberidea cf. T. cubensis (van den Bold, 1946), (5) exterior right valve, adult female carapace, upper Eocene, 612-18X-3, USNM 401525, (6) interior left valve, adult female, middle Eocene, 612-23X-3, USNM 401524. 


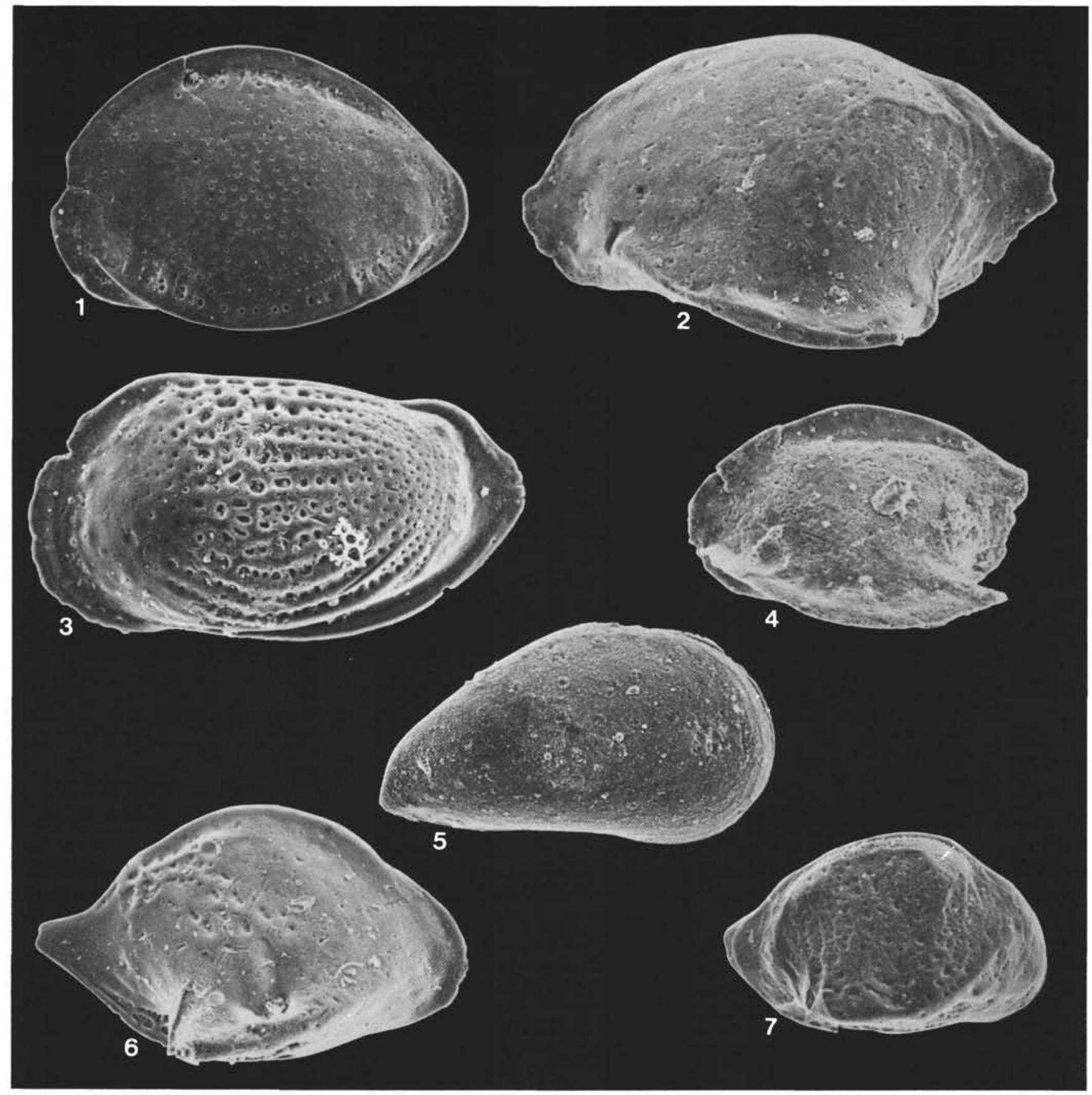

Plate 5. (Three-part designations beginning with 612 or 613 are DSDP section numbers.) 1. "Eocytheropteron" trinidadensis (van den Bold, 1960), $\times 120$, exterior left valve, adult female, lower Pliocene, 613-17X-3, USNM 401528. 2, 4, 6. Cytheropteron spp., $\times 150$, adult female, middle Eocene, $(2,4)$ exterior left valve (2, 612-22X-3, USNM 401529.; 4, 612-24X-3, USNM 401531), (6) exterior right valve, 612-23X-3, USNM 401532. 3. "Loxoconcha" sp., $\times 180$, exterior left valve, adult male, middle Eocene, 612-26X-3, USNM 401533. 5. Eucythere sp., $\times 150$, exterior right valve, adult female, middle Eocene, 612-22X-3, USNM 401535. 7. Cytheropteron nodosum Brady, 1868, $\times 120$, exterior right valve, adult female, Pleistocene, 613-10W-3, USNM 401530. 

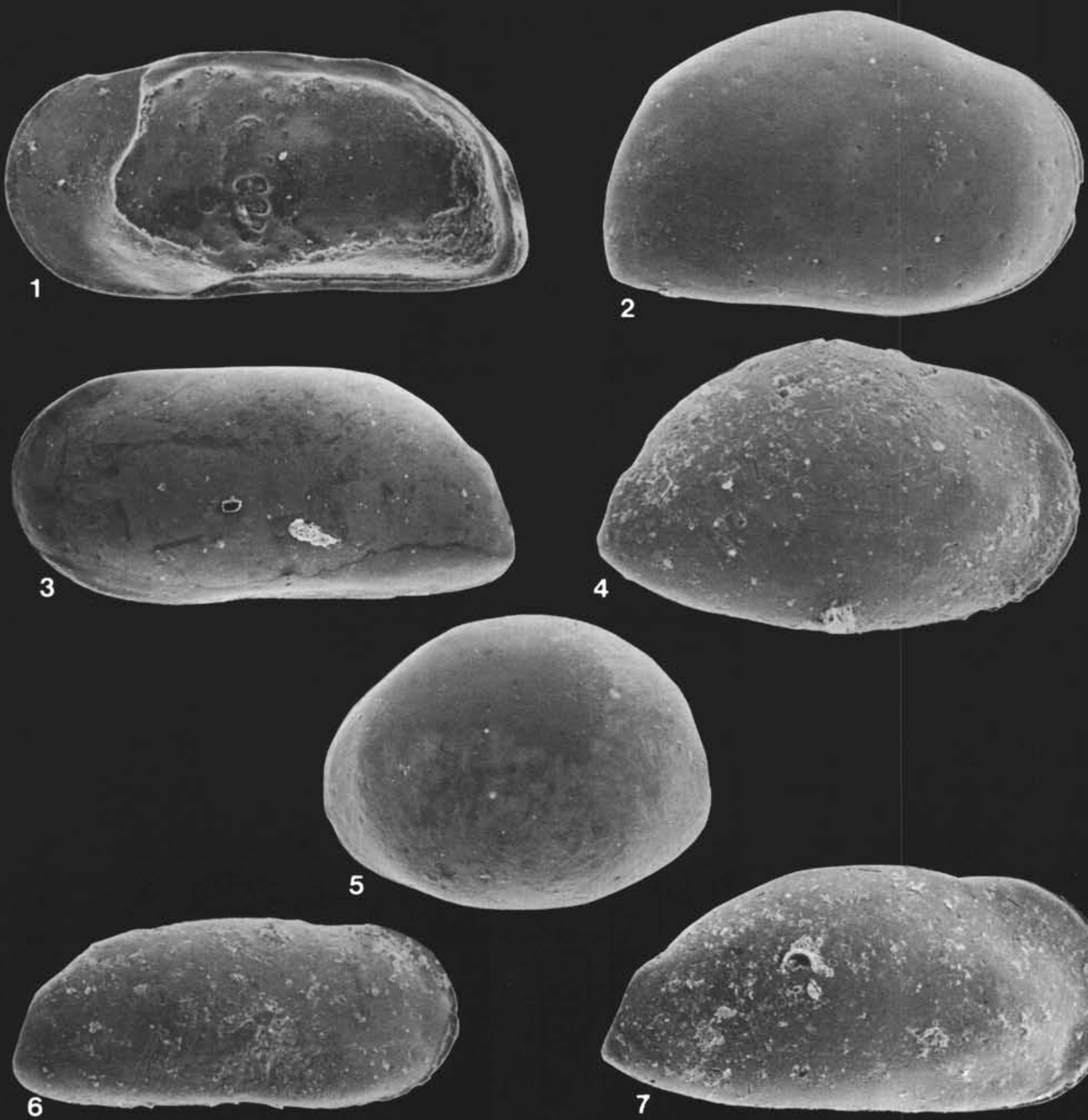

\section{4}

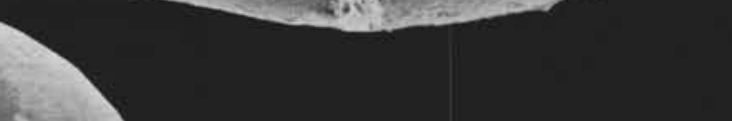




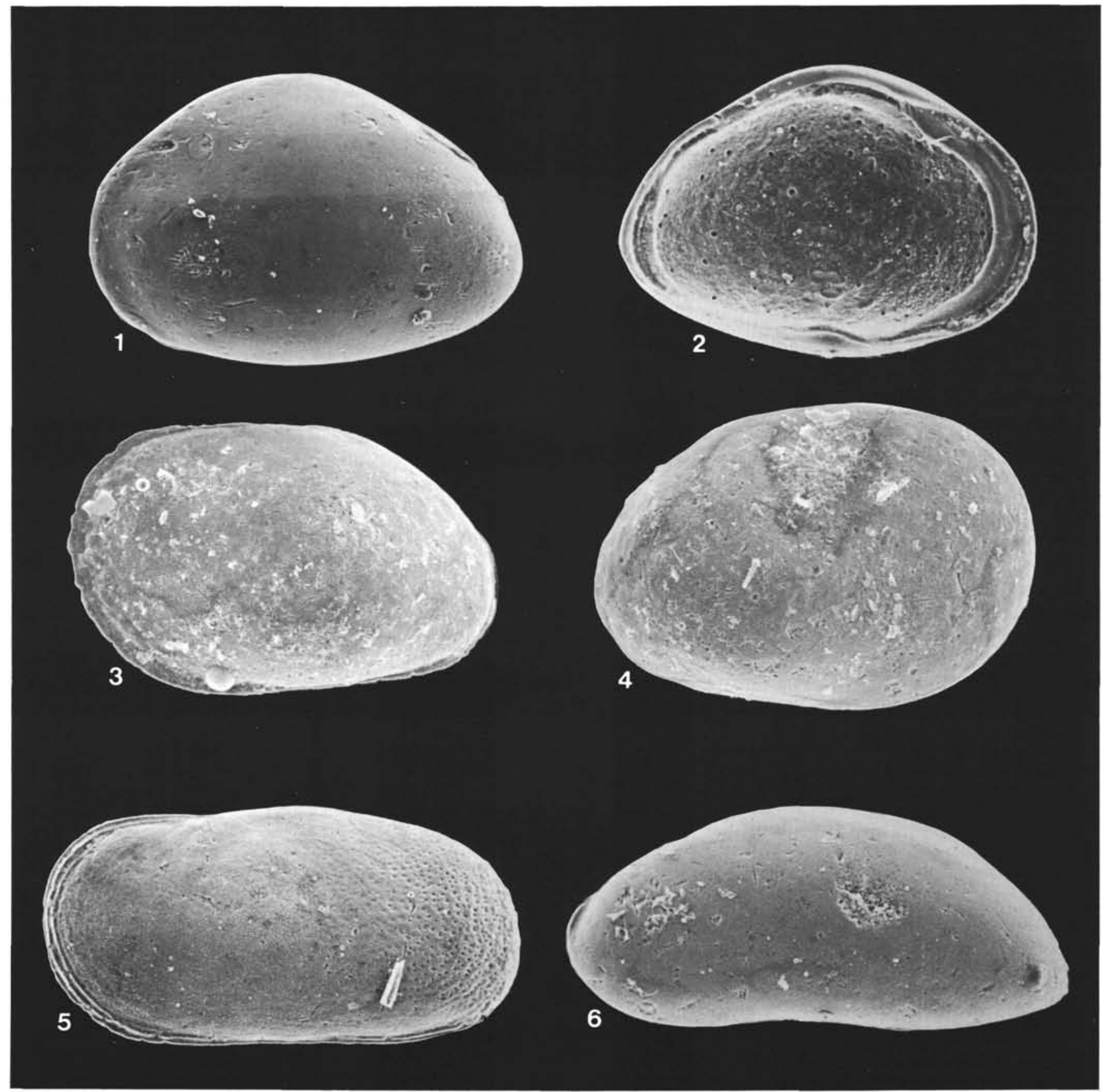

Plate 7. (Three-part designations beginning with 612 or 613 are DSDP section numbers.) 1, 2. Messinella guanajayensis (van den Bold, 1946), $\times 120$, adult female, upper Eocene, 612-18X-3, (1) exterior left valve, USNM 401546. (2) interior left valve, USNM 401547. 3, 4. Cytherella sp. B, adult female, middle Eocene, 613-35X-3, (3) $\times 94$, exterior left valve, USNM 401536, (4) $\times 120$, exterior right valve, USNM 401537. 5. Cytherella sp. A, $\times 100$, exterior left valve, adult female, upper Eocene, 612-17X-3, USNM 401534. 6. Argilloecia sp., $\times 150$, exterior left valve, middle Eocene, 612-22X-3, USNM 401545. 


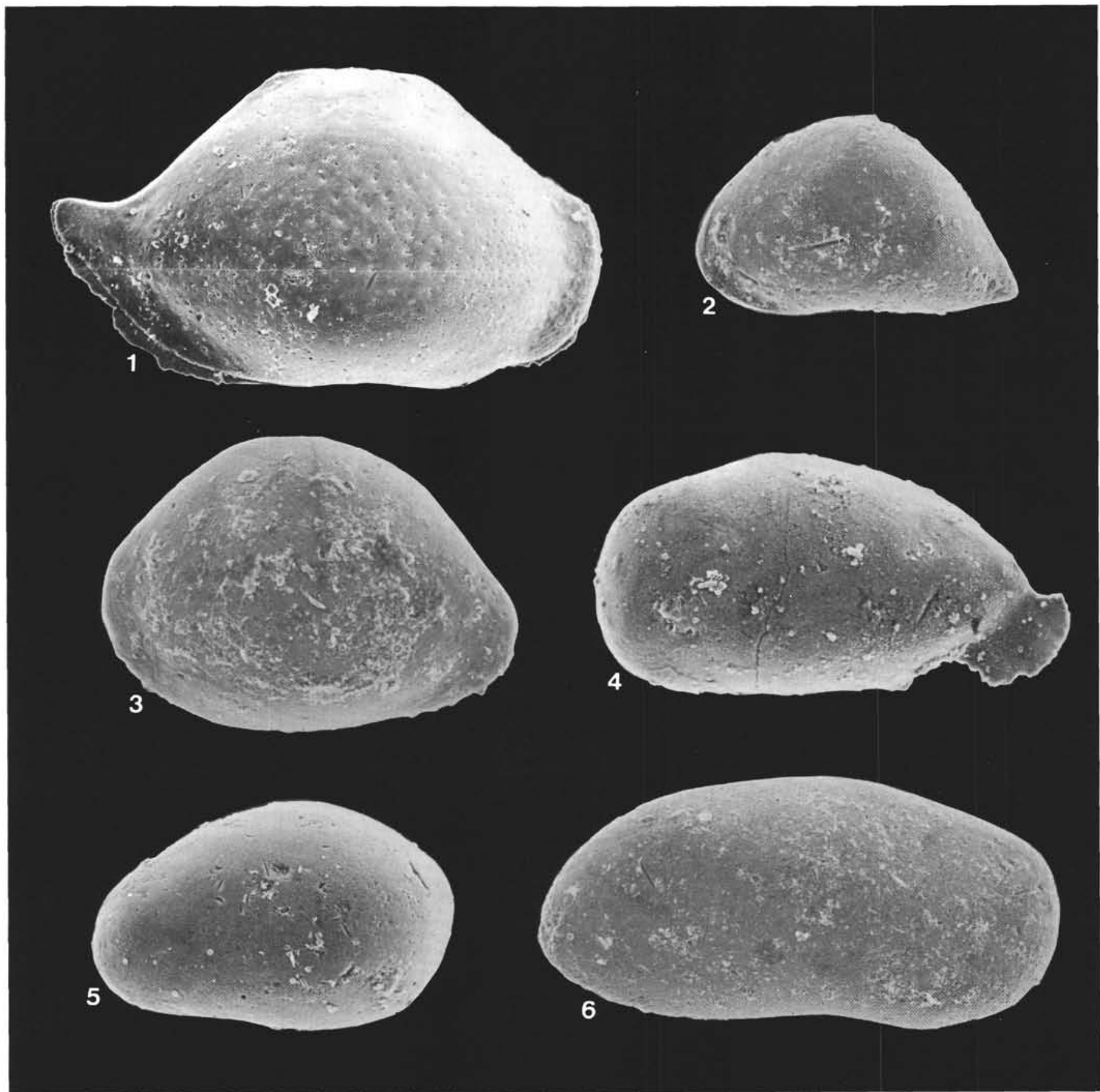

Plate 8. (All specimens are middle Eocene. Three-part designations beginning with 612 or 613 are DSDP section numbers.) 1. Bairdoppilata cf. B. cassida (van den Bold, 1946), ×78, exterior right valve, adult female?, 612-25X-3, USNM 401548. 2. "Bairdia" sp., $\times 120$, exterior left valve, adult female, 613-23X-1, USNM 401551. 3. Paranesidea $\mathrm{cf}$. P. cespedesensis (van den Bold, 1946), $\times 110$, exterior left valve, juvenile female, 613-25X-3, USNM 401549. 4. Aratrocypris sp., $\times 180$, exterior left valve, adult male, 612-24X-3, USNM 401553. 5. Xestoleberis sp., $\times 150$, exterior left valve, adult female, $612-22 \mathrm{X}-3$, USNM 401552. 6. Bythocypris sp., $\times 86$, exterior right valve, adult male, $613-23 \mathrm{X}-1$, USNM 401550. 